Creative Commons User License: CC BY-NC-ND

Abstracted by: EBSCOhost, Electronic Journals Service (EJS)

Google Scholar, Journal Seek, Scientific Commons,

Food and Agricultural Organization (FAO), CABI and Scopus
Journal of Agricultural Extension

Vol. 23 (1) January, 2019

ISSN(e): 24086851; ISSN(Print); 1119944X

http://journal.aesonnigeria.org

http://www.ajol.info/index.php/iae

Email: editorinchief@aesonnigeria.org

\title{
Perceived Benefits of Adoption of Improved Rice Production Technologies Among Small-Scale Farmers in Kogi state, Nigeria.
}

https://dx.doi.org/10.4314/jae.v23i1.12

Adisa, Rashid Solagberun

Department of Agricultural Extension and Rural Development, University of Ilorin, Ilorin

Email: rsadisa@yahoo.com; Phone: +2348037523892

\section{Ahmed, Tijani Abdulhamid}

Department of Agricultural Economics and Extension, Kogi State University, Anyigba

Email: ahmed.ta@ksu.edu.ng; Phone: +2348067691997

\section{Ebenehi, Ojomugbokenyode}

Department of Agricultural Economics and Extension, Kogi State University, Anyigba

Email: Ebenehi.o@gmail.com; Phone: +2348063745147

\section{Oyibo, Felix Ojochogwu}

Department of Agricultural Economics and Extension, Kogi State University, Anyigba

Email: callmefelixoyibo@gmail.com; Phone: +2348039682755

\section{Abstract}

The study examined the benefits of adoption of improved rice technologies among small - scale rice farmers in Kogi State, Nigeria. The specific objectives were to; describe the socio - economic characteristics of the rice farmers, assessed farmers' level of adoption of improved rice technologies, identify the rice farmers' sources of agricultural information and source of information preferred, identify the benefits derived from adoption and identify the constraints to rice production in the area. Primary and secondary data were used for the study. Data were collected using structured questionnaire from 212 rice farmers. Data collected were analysed using descriptive statistics. Results show that $59.9 \%$ of the respondents were male, and within the ages of $40-49$ years. The majority (58.0\%) of the respondents were married and $60.8 \%$ of the farmers depend on extension agents for agricultural information. The improved technologies disseminated; rice production facilities, rice farming inputs, field preparation were adopted with adoption index of $0.70,0.71$ and 0.77 respectively indicating high adoption level, while processing technologies had low adoption level with adoption index of 0.37. Increased output (98.6\%), acquisition of skills (91.5\%), increase in income (85.5\%) and expansion of farm land $(72.2 \%)$ were the major benefits derived by the farmers from adoption of the technologies. The study concluded that the major benefits derived from adoption of the technologies were increased farm size, increased output and 
Creative Commons User License: CC BY-NC-ND

Abstracted by: EBSCOhost, Electronic Journals Service (EJS)

Google Scholar, Journal Seek, Scientific Commons,

Food and Agricultural Organization (FAO), CABI and Scopus
Journal of Agricultural Extension

Vol. 23 (1) January, 2019

ISSN(e): 24086851; ISSN(Print); 1119944X

http://journal.aesonnigeria.org

http://www.ajol.info/index.php/iae

Email: editorinchief@aesonnigeria.org

http://eoi.citefactor.org/10.11226/v23i1

income, and the major constraints to rice production were inadequate finance and credit facilities and poor soil fertility. Extension agents should encourage the farmers to re-invest their income for more output and income. Government and financial institutions should also provide the farmers with production credit in form of loan at low interest rate, so that they can afford some of the technologies

Keywords: Adoption, benefit derived, improved rice technologies

\section{Introduction}

Rice is the seed of the grass species Oryza sativa (Asian rice) or Oryza glaberrima (African rice). Rice is the most commonly cultivated cereal throughout the world today. The African rice is believed to have originated from the wild rice (O. barthii) about 3500 years ago and was domesticated in the inland delta area of Nigeria from where it spread to other parts of Africa (Onu, 2018). The demand for rice in Nigeria is growing faster than any other major staple food with consumption broadening across all socio-economic classes including the poor. Rice has become a staple food in Nigeria such that every household; both the rich and the poor consumes a great quantity (Godwin, 2012). Rice is one of the most widely and commonly consumed staples. Milled rice consumption has increased significantly over the years from 240 metric tons in 1961 to 850 metric tons in 1981, and 2757 metric tons in 1991 to 4970 metric tons in 2011 (FAO, 2014).

Increased agricultural productivity depends primarily upon the acceptance of cultural and technological changes at the rural farm level. Thus, for Nigerian agriculture to improve, our farmers have no alternative but to learn and adopt recommended scientific farming techniques in place of their traditional practices. Perhaps, the slow development of Nigerian agriculture can be attributed to the inability of the Nigerian farmers to respond positively to new ideas or innovations (Umeh, Igwe and Anyim, 2018).

It is assumed that notable improvements can take place in Nigerian agriculture, if the available technologies are accepted and adopted by the farmers. To harness the rich agricultural potential of the area, to promote local rice production and to reduce imports of food crops that can be produced locally, improved rice production technologies were extended (disseminated), yet some farmers in the area still maintained their old methods of production and traditionally grow unimproved varieties of rice. Their yields are usually low, keeping the farmers at a subsistence level of production. Farmers must acquire new skills, ideas, and techniques in order to get profit from their enterprises (Adisa et al., 2018).

Government services continue to suffer from a number of shortcomings. They tend to be bureaucratic and inefficient. Instead of consulting farmers about their needs, government extension agents generally decide what is best for them (CTA, 2012). What attract farmers basically to adoption of certain innovations are the benefits they derived or enjoyed from adopting particular technologies.

It is in this context that the study was conducted to gain understanding into the benefits derived from adoption of improved rice technologies disseminated to the rice farmers. The specific objectives of the study are to: identify the socio - economic characteristics of the farmers; to determine the rice farmer's sources of information and source of information 
Creative Commons User License: CC BY-NC-ND

Abstracted by: EBSCOhost, Electronic Journals Service (EJS)

Google Scholar, Journal Seek, Scientific Commons,

Food and Agricultural Organization (FAO), CABI and Scopus
Journal of Agricultural Extension

Vol. 23 (1) January, 2019

ISSN(e): 24086851; ISSN(Print); 1119944X

http://journal.aesonnigeria.org

http://www.ajol.info/index.php/jae

Email: editorinchief@aesonnigeria.org

preferred; and to determine the rice farmer's level of adoption of improved rice technologies; to identify the benefits derived from adoption of improved rice technologies and to identify the constraints to rice production in the study area.

\section{Methodology}

This study was conducted in Kogi State. The State lies on latitude $49^{\circ} 71^{\prime}$ North and longitude $45^{\circ} 61^{\prime}$ East with a geological feature depicting young sedimentary rocks and alluvium along the riverbeds, which promotes agricultural activities and has an average maximum temperature of $33.2^{\circ} \mathrm{C}$ and average minimum of $22.8^{\circ} \mathrm{C}$ (Ahmed and Adisa, 2017). The state has a total land area of $28,313.53$ square kilometres and population of 3.3 million people (NPC, 2006).

The study made use of primary data obtained through the use of questionnaire administered to the respondents, with the aid of well-trained enumerators. Descriptive statistics was used to analyse the data collected. A 5-stage sampling technique was used. Kogi state has 21 local governments. The first stage involves the listing of all major rice producing local governments. The second stage involves random selection of four rice producing local governments. These include Lokoja, Kogi, Idah and Ibaji local government. Third stage involves listing of rice producing villages in each of the local government selected. The fourth stage involves random selection of two rice producing villages from each of the local government selected. The fifth stage involves a random selection of twenty-eight (28) rice farmers from each of the selected villages, giving a total of $(28 \times 4 \times 2)=224$ respondents for the study but 212 questionnaires were returned. The adoption levels of the various innovations introduced to the rice farmers by the extension agents were placed on a 5-point Likert type adoption scale where the farmers were asked to indicate their adoption stage on the 5-point adoption scale. Their response categories and the corresponding weighted values were as follows: Aware $=1$, Interest $=2$, Evaluation $=3$, Trial $=4$ and Adoption $=5$, this was used for the computation of the total mean (M) adoption score per innovation. Innovations with means score of 1 were regarded to be at the awareness stage, Interest $=2$, Evaluation $=$ 3 , Trial $=4$ and Adoption $=5$. The grand mean $(\mathrm{M})$ adoption score was calculated by adding all the total mean adoption scores and dividing them by the number of innovations considered. The adoption index was computed by dividing the grand mean (M) adoption score by 5 (i.e. the 5 -stages of adoption). Adoption index between $0.5-1$ were considered high level of adoption. The constraints to rice production was measured by rating the various constraints on a 3 point Likert scale of Serious Constraints (SC), Mild Constraints (MC), Not a Constraint (NC) with nominal values of 1,2 , and 3 respectively. The weighted means were computed as 2 . Constraints with mean scores of 2 and above were considered serious enough to constrain rice production in the area.

\section{Results and Discussion}

\section{Socio - economic Characteristics of Rice Farmers}

Table 1 presents the relevant socio-economic characteristics of the rice farmers. The results on the table shows that most $(30.7 \%)$ of the respondents were within the age range of $40-$ 49 years. The mean age of the respondents was 43.5 years, which indicates that the majority of the rice farmers were in their prime or productive age. This is in line with the findings of 
Creative Commons User License: CC BY-NC-ND

Abstracted by: EBSCOhost, Electronic Journals Service (EJS)

Google Scholar, Journal Seek, Scientific Commons,

Food and Agricultural Organization (FAO), CABI and Scopus
Journal of Agricultural Extension

Vol. 23 (1) January, 2019

ISSN(e): 24086851; ISSN(Print); 1119944X

http://journal.aesonnigeria.org

http://www.ajol.info/index.php/iae

Email: editorinchief@aesonnigeria.org

http://eoi.citefactor.org/10.11226/v23i1

Nwalieji and Uzuegbunam (2012) that the majority of the rice producers in Anambra and Ebonyi states were still within their middle, active and productive ages and hence can engage efficiently in such rice enterprise. Tables 1 revealed that the majority $(59.9 \%)$ of the respondents were male, while $40.1 \%$ were female. This indicates that they were more male rice farmers dominating rice production in the area. Opaluwa (2014) reported that $89.5 \%$ of farmers in Kogi were males. The table also show that most $(58 \%)$ of the respondents were married, while $24.1 \%$ were single. This conforms to the findings of Adisa, et al., (2018) who found that Majority (97.0\%) of the respondents are married. It shows that they have the necessary experience to relate well with farming households, especially when handling delicate issues such as settling of family disputes. Educational level has been seen as a factor influencing the personality of an individual. As shown in Table 1 most (53.3\%) of the respondents had secondary education, $30.2 \%$ had tertiary education. About $6.6 \%$ of the respondents had no formal education. This is in agreement with Umeh, Igwe and Anyim (2018), who reported that $50.9 \%$ of the respondents had secondary school level of education. Table 1 shows that about $27.8 \%$ of the respondents earned between N51000 - N100 000 annually, 22.6\% earned both between N101 000 - N150 000 and above N200 000, 15.1\% earned between N151 000 - N200 000 while 11.8\% earned less than N50 000. This is in accordance with the findings of Adejo et al. (2016) who reported that the respondents generally were of low income; which can affect adoption of capital intensive modern farm technologies.

Table 1: Socio-economic characteristics of the respondents

\begin{tabular}{|c|c|c|}
\hline Variables & Percentage $(n=212)$ & Mean \\
\hline \multicolumn{3}{|l|}{ Sex } \\
\hline Male & 59.9 & \\
\hline Female & 40.1 & \\
\hline \multicolumn{3}{|l|}{ Age (Years) } \\
\hline $10-19$ & 1.9 & 43.5 \\
\hline $20-29$ & 10.8 & \\
\hline $30-39$ & 24.5 & \\
\hline $40-49$ & 30.7 & \\
\hline $50-59$ & 23.6 & \\
\hline $60-69$ & 7.1 & \\
\hline $70-79$ & 1.4 & \\
\hline \multicolumn{3}{|l|}{ Marital status } \\
\hline Single & 24.1 & \\
\hline Married & 58.0 & \\
\hline Divorced & & \\
\hline Widowed & 10.4 & \\
\hline \multicolumn{3}{|l|}{ Educational level } \\
\hline Primary education & 8.0 & \\
\hline Secondary education & 53.3 & \\
\hline Tertiary education & 30.2 & \\
\hline \multirow{2}{*}{\multicolumn{3}{|c|}{ Annual income }} \\
\hline & & \\
\hline$<N 50,000$ & 11.8 & $\mathrm{~N} 115,787.77 \mathrm{k}$ \\
\hline $\mathrm{N} 51,000-\mathrm{N} 100,000$ & 27.8 & \\
\hline $\mathrm{N} 101,000-\mathrm{N} 150,000$ & 22.6 & \\
\hline $\mathrm{N} 151,000-\mathrm{N} 200,000$ & 15.1 & \\
\hline$>\mathrm{N} 200,000$ & 22.6 & \\
\hline \multicolumn{3}{|l|}{ Rice output level } \\
\hline$<10$ bags/ha & 47.2 & \\
\hline $10-30$ bags $/ \mathrm{ha}$ & 32.1 & \\
\hline $31-40$ bags $/ \mathrm{ha}$ & 15.6 & \\
\hline$>40$ bags/ha & 5.2 & \\
\hline
\end{tabular}

Source: Field Survey, 2015 
Creative Commons User License: CC BY-NC-ND

Abstracted by: EBSCOhost, Electronic Journals Service (EJS),

Google Scholar, Journal Seek, Scientific Commons,

Food and Agricultural Organization (FAO), CABI and Scopus
Journal of Agricultural Extension

Vol. 23 (1) January, 2019

ISSN(e): 24086851; ISSN(Print); 1119944X

http://journal.aesonnigeria.org

http://www.ajol.info/index.php/jae

Email: editorinchief@aesonnigeria.org

\section{Respondent's Sources of Agricultural Information Used and Preferred}

Most of the respondents use more than one source of information on agricultural production. Table 2 revealed that the majority $(60.8 \%)$ of the respondents depends on extension agents for information on rice production, and $32.1 \%$ used radio as source of information. The table also revealed that the majority $(63.7 \%)$ of the respondents preferred extension agents as source of information on rice production, followed by radio (15.6\%), and other sources $(1.4 \%)$ used were given by the respondents as friends and relatives. Nigeria cannot achieve increased agricultural productivity on rural farm level, except through the provision of basic agricultural education, particularly, the non-formal form which is the extension type that will help move millions of the farmers from traditional to progressive farming, thereby improving the overall quality of rural life. The ability of famers to contribute and participate effectively towards agricultural development depends on their ability to optimize the services of agricultural extension agents (Umeh, Igwe and Anyim, 2018). The low percentage of the farmers' preference for radio and television despite their effectiveness in information dissemination could be attributed to inaccessibility due to cost of procurement, problem of electricity, time of broadcasting, and the fact that radio and television are less interactive because they are one-way process of communication.

\section{Table 2: Sources of information used and preferred by the rice farmers}

\begin{tabular}{lll}
\hline Sources of & Used Sources & Preferred Sources \\
\cline { 2 - 3 } Information & Percentage $(\mathrm{n}=212)$ & Percentage $(\mathrm{n}=212)$ \\
\hline Radio & 32.1 & 15.6 \\
Television & 1.9 & 3.3 \\
Extension agents & 60.8 & 63.7 \\
Cooperative societies & 1.4 & 7.1 \\
Other farmers & 6.6 & 9.0 \\
Internet & 0.5 & 0 \\
Other sources & 2.4 & 1.4 \\
\hline \multicolumn{2}{l}{ Source: field survey, $2015 \quad$ Multiple Responses recorded }
\end{tabular}

\section{Level of Adoption of Improved Technologies among the Rice Farmers}

The result on Table 3 shows the level of adoption of improved rice production facilities, rice farming inputs, field preparation/planting, and harvesting/processing. Rice production facilities had 3.5 (approx. 4.0) grand mean of adoption and had above $50 \%$ adoption ratio with adoption index of 0.70 , indicating that the adoption of rice production facilities were above average. On the 5-point adoption scale, the 4.0 grand mean implies that the farmers were at the trial stage of adoption. This is in consonance with Mustapha et al., 2012 who found that majority of the respondents tried rice production technologies with respect to high yielding varieties $(77.5 \%)$, early maturing varieties $(69.37 \%)$, broadcasting methods $(55.0 \%)$ and bagging (63.75) and finally adopted the technologies.

Rice Farming Inputs: Table 3 also indicates that the grand mean was 3.6 for the rice farming inputs. The implication of this is that the farmers were also at the trial stage on the 5point adoption scale. The adoption index of 0.73 indicates that the farmers were above 
Creative Commons User License: CC BY-NC-ND

Abstracted by: EBSCOhost, Electronic Journals Service (EJS) Google Scholar, Journal Seek, Scientific Commons,

Food and Agricultural Organization (FAO), CABI and Scopus
Journal of Agricultural Extension

Vol. 23 (1) January, 2019

ISSN(e): 24086851; ISSN(Print); 1119944X

http://journal.aesonnigeria.org

http://www.ajol.info/index.php/iae

Email: editorinchief@aesonnigeria.org

average in the adoption of various improved rice farming inputs, that is, $73 \%$ of the farming inputs were adopted. Generating agricultural technologies is meaningful only when they are adopted at the farm level (Onu, 2018).

Field Preparation/Planting: table 3 also shows that field preparation/planting had adoption index of 0.77 showing that field preparation/planting technologies were adopted above average $(77 \%)$. The $25 \mathrm{~cm}$ by $25 \mathrm{~cm}$ planting space with mean adoption score of 4.56 was adopted approximately. The grand mean for field preparation/planting is 3.9 which imply that the farmers were at the trial stage on the 5-point adoption scale. Uwandu, Thomas and Okoro (2018) reported that higher proportion (33.6\%) of the respondents involved in crop farming adopted crop technologies like recommended crop spacing, pesticides application, and pest and disease control.

Harvesting and Processing Technologies: harvesting and processing facilities had an adoption index of 0.37 ; this indicates that only harvesting and processing facilities were adopted below average. It shows the low rate of adoption and processing facilities by the farmers. This could be as a result of the high cost of these facilities, beyond what small scale rice farmers can afford. This is in line with Onu (2018) who asserted that the majority of rice production and processing in Nigeria is in the hands of resource poor subsistent farmers who lack the economic and social power to fully adopt technologies. Availability of a sustainable rice processing technology for Nigerian resource-poor rice farmers is important if the country's effort at achieving self-sufficiency in rice production must be achieved. Also, Uwandu, Thomas and Okoro reported that only $8.3 \%$ each adopted thresher and sickle respectively. 
Creative Commons User License: CC BY-NC-ND

Abstracted by: EBSCOhost, Electronic Journals Servi

Google Scholar, Journal Seek, Scientific Commons,

Food and Agricultural Organization (FAO), CABI and Scopus

http://eoi.citefactor.org/10.11226/v23i1
Journal of Agricultural Extension

Vol. 23 (1) January, 2019

ISSN(e): 24086851; ISSN(Print); 1119944X

http://journal.aesonnigeria.org

http://www.ajol.info/index.php/iae

Email: editorinchief@aesonnigeria.org

Table 3: Respondents level of adoption of improved technologies

\begin{tabular}{lccc}
\hline Technologies Disseminated & Mean & Grand Mean & Adoption Index \\
\hline Rice production facilities & 3.82 & & \\
Tube well & 2.06 & 3.50 & 0.70 \\
Bore hole & 3.58 & & \\
Bird-scarer & 4.54 & & \\
Knapsack sprayer & 4.82 & & 0.71 \\
Rice farming inputs & & 3.63 & \\
Improved Variety (FARO44,ITA150 & 4.78 & & \\
Fertilizer (NPK 20:20:20) & 3.49 & & \\
Herbicide (mixture;stamF34,delmin,Ronstar) & 3.44 & & \\
Pesticide;Furadan,Basudin,Marsha & 1.64 & & \\
Rodenticide & 4.56 & & \\
Field preparation/planting distance & & & \\
25 by 25 planting method & 3.33 & & \\
Ploughing & 3.43 & 3.87 & \\
Harrowing & 4.26 & & \\
Water management & 4.00 & & \\
Seed selection & 3.63 & & \\
Seed testing & & & \\
Processing & 1.85 & & \\
Combine harvester & 1.80 & & \\
Per boiler & 1.84 & \\
Dryer & 1.94 & & \\
De-stoner & & & \\
Packaging equipment (Bag, sewing and hot sealing & 1.78 & \\
machines) & &
\end{tabular}

Source: Field Survey, 2015.

\section{Rice Farmer's Benefits Derived from Adoption of Improved Technologies}

Table 4 shows the distribution of the respondents by the benefits/achievement derived from their involvement in agricultural extension activities and for adopting some of the improved technologies disseminated. Results from the table shows that the majority $(98.6 \%)$ of the respondents had increase in their rice output as a result of their contact with extension agents and their involvement in extension activities and adoption of the technologies disseminated. This in line with Mustapha et al., (2012) who recorded that rice yield could increase due to growers using improved rice varieties which have potentials to improve nutrition, boost food security, foster rural development and support sustainable land care. This is expected because of the yielding potentials of the improved varieties. 
Creative Commons User License: CC BY-NC-ND

Abstracted by: EBSCOhost, Electronic Journals Service (EJS),

Google Scholar, Journal Seek, Scientific Commons,

Food and Agricultural Organization (FAO), CABI and Scopus

http://eoi.citefactor.org/10.11226/v23i1
Journal of Agricultural Extension

Vol. 23 (1) January, 2019

ISSN(e): 24086851; ISSN(Print); 1119944X

http://journal.aesonnigeria.org

http://www.ajol.info/index.php/jae

Email: editorinchief@aesonnigeria.org

Table 4: Benefits derived from adoption of improved technologies

\begin{tabular}{lll}
\hline Benefits & Yes $(\%) \quad \mathrm{n}=212$ & Rank \\
\hline Increased output & 98.6 & $1^{\text {st }}$ \\
Acquire more skills & 91.5 & $2^{\text {nd }}$ \\
Increase in farm income & 85.8 & $3^{\text {rd }}$ \\
Farm expansion & 72.2 & $4^{\text {th }}$ \\
Adoption of more farm technologies & 31.1 & $5^{\text {th }}$ \\
Acquisition of more farm land & 26.9 & $6^{\text {th }}$ \\
Purchase tractor & 1.4 & $7^{\text {th }}$ \\
Others (specified).................. & & \\
\hline Source: Field Survey, $2015 \quad$ Multiple Responses Recorded &
\end{tabular}

Furthermore, the majority (72.2\%) of the respondents expanded their farm land, that is, area of land under rice cultivation. The expansion of area of land under rice cultivation could be the reason for the increase in rice output and this is in consonance The table further indicates that $26.9 \%$ of the respondents acquire more farm land while the majority $(73.1 \%)$ did not acquire more farm land, only $1.4 \%$ purchased tractor while $98.6 \%$ did not. Also, the majority $(85.8 \%)$ of the respondents had increase in their farm income, even though their income was generally low, while only $14.2 \%$ complained of no increment in their farm income. When other things are held constant, there is obviously a positive relationship between level of income and adoption of innovations.

The majority $(91.5 \%)$ of the respondents acquired more skills for rice production. About $31.1 \%$ of the respondents adopted more farm technologies while the majority $(68.9 \%)$ of the respondents did not adopt more farm technologies, this may be as a result of high cost of production technologies, late/untimely information, and inadequate knowledge of technologies given by the respondents as reasons for not adopting some of the technologies. The success of any diffusion of innovations depends not only on its rate and level of adoption among the potential users but also on the benefits derived from adoption of such innovations.

Other benefits specified by the respondents were improved family welfare, renovation of houses, purchase of motor cycle, increased in the quantity of rice for domestic consumption, payment of hospital bills and school fees which can leads to improved children education and improved health status. All these could lead to reduction in the level of poverty which has diverse economic and social dimensions that explain its manifestations in lack of income and insufficient productive resources to ensure sustainable livelihood.

\section{Farmer's Constraints to Rice Production}

Table 5 shows that inadequate finance and credit facilities ranked $1^{\text {st }}(\bar{x}=2.75)$ as the most serious constraints to rice production in the study area, poor soil fertility ranked $2^{\text {nd }}$ $(\bar{x}=2.69)$, inadequate size of farm land ranked $3^{\text {rd }}(\bar{x}=2.58)$, followed by lack of adequate and timely information $(\bar{x}=2.52)$, and excessive weed $(\bar{x}=2.50)$. Approximately, all these constraints can be regarded as most serious constraints to rice production in the study area. 
Creative Commons User License: CC BY-NC-ND

Abstracted by: EBSCOhost, Electronic Journals Service (EJS),

Google Scholar, Journal Seek, Scientific Commons,

Food and Agricultural Organization (FAO), CABI and Scopus

http://eoi.citefactor.org/10.11226/v23i1

Ebenehi et al., (2018) reported that inadequate fund hinders farmers from getting the necessary resources and technologies which assist to adapt successfully to climate change among crop farmers.

\section{Table 5: Farmers constraints to rice production}

\begin{tabular}{lll}
\hline Constraints & Mean & Rank \\
\hline Inadequate finance and credit facilities & 2.75 & $1^{\text {st }}$ \\
Poor soil fertility & 2.69 & $2^{\text {nd }}$ \\
Inadequate size of farmland & 2.58 & $3^{\text {rd }}$ \\
Lack of adequate and timely information & 2.52 & $4 \mathrm{~h}$ \\
Excessive weed/pest and disease infestation & 2.51 & $5^{\text {th }}$ \\
Soil erosion problem and flood & 2.38 & $6^{\text {th }}$ \\
High cost of farm inputs & 2.36 & $7^{\text {th }}$ \\
Inadequate/Lack of seed testing laboratories & 2.27 & $8^{\text {th }}$ \\
Poor access roads and other infrastructures & 2.25 & $9^{\text {th }}$ \\
Absence of processing facilities & 2.18 & $10^{\text {th }}$ \\
Inadequate supply of farm input & 2.17 & $11^{\text {th }}$ \\
Lack of transport facilities & 2.01 & $12^{\text {th }}$ \\
Non - availability of market for rice produce & 1.99 & $13^{\text {th }}$ \\
\hline
\end{tabular}

Source: Field Survey, 2015

Also, soil erosion problem and flood ranked $6^{\text {th }}(\bar{x}=2.38)$, high cost of farm inputs ranked $7^{\text {th }}$ $(\bar{x}=2.36)$, lack of seed testing laboratories ranked $8^{\text {th }}(\bar{x}=2.27)$, poor access roads and other infrastructure ranked $9^{\text {th }}(\bar{x}=2.25)$, followed by absence/inadequate processing facilities $(\bar{x}=2.18)$, inadequate supply of farm inputs $(\bar{x}=2.17)$, lack of transport facilities $(\bar{x}=2.10)$, and non - availability of market for rice produce $(\bar{x}=1.99)$

\section{Conclusion and Recommendations}

The major benefits derived were; the respondents expanded the area of land under rice cultivation, had increased in their rice output and increased in their farm income for adopting some of the technologies. The major constraints to rice production in the study area were inadequate finance and credit facilities, followed by poor soil fertility, inadequate size of farm land, lack of adequate and timely information, and excessive weed. Government and financial institutions should also provide the farmers with production credit in form of loan at low interest rate, so that they can afford some of the technologies. Also, Funds should be made available and timely for the extension institutions to carry out their extension activities and to remobilize extension agents for more effective extension work. In addition, there should be adequate training for the rice farmers on improved technologies and the dissemination of relevant technologies should be timely. Specifically, the extension training should focus more on the rice processing technologies.

\section{References}

Adejo, P. E., Adejo, S. O., Ahmed, T. A. and Bello, D. (2016). Assessment of the use of Rural Radio as an Agricultural Information Dissemination Tool among Rural Farmers in Dekina Local Government of Kogi State, Nigeria. International Journal 
Creative Commons User License: CC BY-NC-ND

Abstracted by: EBSCOhost, Electronic Journals Service (EJS), Google Scholar, Journal Seek, Scientific Commons,

Food and Agricultural Organization (FAO), CABI and Scopus

http://eoi.citefactor.org/10.11226/v23i1

of Agricultural Science, Research and Education Systems (IJASRT in EESs) shoushtar.ac.ir. 2016: 6(2):65-70
Journal of Agricultural Extension

Vol. 23 (1) January, 2019

ISSN(e): 24086851; ISSN(Print); 1119944X

http://journal.aesonnigeria.org

http://www.ajol.info/index.php/iae

Email: editorinchief@aesonnigeria.org

Technology in Extension and

Available online on: http://ijasrt.iau-

Adisa, R. S., Mustapha, A. M., Balogun, K. S., Ibrahim, H. K, and Oloyede W. O. (2018). Analysis of Farm Management Extension Services Performed By Extension Agents of Agricultural Development Projects in Southwest Nigeria. International Journal of Agricultural Science, Research and Technology in Extension and Education Systems (IJASRT in EESs) Available online on: http://ijasrt.iau-shoushtar.ac.ir. ISSN: 2251-7596 Online. 2018: 8(1):7-15

Ahmed T. A. and Adisa R. S. (2017). Perceived Effectiveness of Agricultural Extension Methods Used to Disseminate Improved Technologies to Rice Farmers in Kogi State, Nigeria. International Journal of Agricultural Science, Research and Technology in Extension and Education Systems (IJASRT in EESs) Available online on: http://ijasrt.iau-shoushtar.ac.ir. 2017: 7(1):27-34

Ebenehi O., Ahmed T. A., and Barnabas T. M. (2018). Evaluation of Extension Services Delivery for Climate Change Adaptation by Crop Farmers in Niger State, Nigeria. Asian Journal of Agricultural Extension, Economics \& Sociology 27(1): 1-13, 2018; Article no. AJAEES.39681 ISSN: 2320-7027

Food and Agriculture Organization of the United Nations Statistics Division (FAOSTAT). (2014). Crop production and trade. Rice production, importation harvested area.

Godwin, U. (2012). Rice farm, milling plant: Sure money spinner. Available at: http://nationalmirroronline.net/new/rice-farm-milling-plant-sure-moneyspinner/. Accessed 15th January 2013.

Mustapha, S. B., Undiandeye U. C., Sanusi, A. M., and Bakari S. (2012). Analysis of Adoption of Improved Rice Production Technologies in JeerLocal Government Area of Borno State, Nigeria. International Journal of Development and Sustainability. Volume1 Number 3 (2012): Pages $1112-1120$.

National Population Commission (NPC) (2006). Population and housing census enumerator manual. Federal Republic of Nigeria, National Population Commission, Nigeria, pp: 1-16.

Nwalieji, H. U. and Uzuegbunam, C. O. (2012). Effects of climate Change on Rice production in Anambra state, Nigeria. Journal of Agricultural extension, vol.

(2), December 2012, pp $81-91$.

Onu, S. E. (2018). Preference for Imported and Nigeria Rice among Rural Households in Imo State Nigeria. Journal of Agricultural Extension. Vol. 22 (3) October, 2018. https://dx.doi.org/10.4314/jae.v22i3.6

Opaluwa, H. I. (2014). Technical efficiency and resource utilization among maize farmers in kogi state, Nigeria. Ph. D research findings submitted to the 
Creative Commons User License: CC BY-NC-ND

Abstracted by: EBSCOhost, Electronic Journals Service (EJS)

Google Scholar, Journal Seek, Scientific Commons,

Food and Agricultural Organization (FAO), CABI and Scopus

http://eoi.citefactor.org/10.11226/v23i1
Journal of Agricultural Extension

Vol. 23 (1) January, 2019

ISSN(e): 24086851; ISSN(Print); 1119944X

http://journal.aesonnigeria.org

http://www.ajol.info/index.php/jae

Email: editorinchief@aesonnigeria.org

Department of Agricultural Economics and Extension, Faculty of Agriculture, Kogi State University.

Technical Centre for Agricultural and Rural Cooperation (CTA) (2012). Agricultural Extension, a time for change: Linking knowledge to policy and action for Food and Livelihood.

Umeh, O. J., Igwe, K. C., and Anyim, A. (2018). Farmers Knowledge of the Role of Extension Services in Akwa-lbom State Nigeria. Journal of Agricultural Extension. Vol. 22 (3) October, 2018. https://dx.doi.org/10.4314/jae.v22i3.9

Uwandu,C. N., Thomas, K. A., and Okoro, C. M. (2018). Utilization of Agricultural Information Sources and Adoption of Animal and Crop Technologies Among Farming Households in Imo State, Nigeria. Journal of Agricultural Extension. Vol. 22 (1) February, 2018. https://dx.doi.org/10.4314/jae.v22i1.13 